\title{
The Design of Patent Pools: The Determinants of Licensing Rules
}

\author{
Josh Lerner, Marcin Strojwas, and Jean Tirole*
}

November 4, 2005

\begin{abstract}
Patent pools are an important but little-studied economic institution. In this paper, we first make a set of predictions about the licensing terms associated with patent pools. The theoretical framework predicts that (a) pools consisting of complementary patents are more likely to allow members to engage in independent licensing and (b) that the requirement that firms license patents to the pool (grantbacks) should be associated with pools that consist of complements and allow independent licensing. We then empirically examine the terms of 63 pools, and show that licensing rules are consistent with these hypotheses.
\end{abstract}

\section{Introduction}

Patent pools can be defined as formal or informal organizations where for-profit firms share patent rights with each other and third parties. To date, this organizational form has attracted little empirical attention from economists. This neglect is unfortunate, since patent pools are particularly interesting for two reasons.

First, the determinants of organizational structure have been a major concern in the industrial organization literature for many decades. While certain hybrids between arm's length contracting and full integration - e.g., joint ventures - have been extensively scrutinized, patent pools

*Harvard University and NBER; Harvard University; and University of Toulouse and Massachusetts Institute of Technology. We thank Chris Allen, Jing-Yuan Chiou, Isidro Ferrer, Andrew Frisbee, Nick Lau, Erika McCaffrey, Franklin Noll, Olga Trzebinska, Sarah Woolverton, Bernard Yoo, and especially Adrian Ma for research assistance. Ken French and Dietmar Harhoff provided us with supplemental data. Audiences at numerous seminars and conferences, Suzanne Majewski, Tom Nicholas, Scott Stern, Dennis Yao, and a number of practitioners provided helpful comments. Harvard Business School's Division of Research and the National Science Foundation provided financial support. 
represent a little-studied organizational structure that may shed light on contracting challenges more generally.

The second motivation is a more practical one. The United States over the past two decades has seen an explosion of patent awards, and a dramatic increase in the volume of patent litigation between rivals. Numerous commentators have suggested that the proliferation of these awards has had socially detrimental consequences: overlapping intellectual property rights may make it difficult for inventors to commercialize new innovations. (Gallini [2002] reviews this literature.) Patent pools have been proposed by Merges [1999], Priest [1977], Shapiro [2000], and the U.S. Patent and Trademark Office (Clark, et al. [2001]) as a way in which firms can address these "patent thicket" problems. Indeed, patent pools are already an economically significant institution: a recent estimate (Clarkson [2003]) suggests that sales in 2001 of devices based in whole or in part on pooled patents were at least $\$ 100$ billion. Were suggestions to facilitate the formation of patent pools to be adopted, their role might approach that seen in the early days of 20th century, when many (if not most) important manufacturing industries had a patent pooling arrangement.

As noted above, there is a very limited amount of related empirical literature. Aoki and Nagaoka [2005], Bittlingmayer [1988], and Cassady [1959] present clinical studies of individual patent pools. Gilbert [2004] provides a historical overview of these pools and introduces some of the methodologies we rely upon here. Legal scholars, however, have written the bulk of the literature on these institutions: Carlson [1999] and Merges [1999] are examples.

The plan of this paper is as follows. Section 2 provides the theoretical framework for the analysis. Patent holders decide whether to join forces and form a pool. The pool's charter specifies whether (a) independent licensing is allowed (in which case individual patent-holders are free to grant licenses on their patents, possibly combined with follow-up innovations), and (b) grantbacks are imposed (in which case innovations that are related to the pool's offering must be transferred at no fee to the pool).

The model posits a cost and a benefit for both of these tools. As was stressed in LernerTirole [2004], independent licensing creates competition by members against the pool's offering if patents are substitutes. ${ }^{1}$ The benefit for members of such licensing is that individual patentholders can take their technology in directions unrelated to the pool and market the outcome; in contrast, in the absence of independent licensing, patent-holders must first secure from the pool (assuming this is doable) a license for the technology they initially conceived. Independent licensing therefore promotes innovation for uses that are unrelated to the pool.

\footnotetext{
${ }^{1}$ As argued in that paper, measuring whether patents are substitutes or complements is in general a difficult matter; besides, the pattern of complementarity/substitutability is price-contingent. Fortunately, independent licensing can be shown to be a perfect screen against anti-competitive pools.
} 
Grantbacks are motivated by the risk that some member at the date of pool formation has knowledge that will lead to a blocking patent and enable her to hold up the pool. Grantbacks, however, come at a cost: It may later happen that an efficient implementation of the pool's technology necessitates a piece of intellectual property that is missing at the date of the formation of the pool. To the extent that courts have a hard time figuring out whether a pool member already knew this and had the idea at the formation of the pool, grantbacks also discourage pool members from completing the range of essential patents and leave the road open for third-party innovators who will then hold up the pool.

Pools of substitutes prohibit independent licensing in order to avoid competition for the pool's technology. But they do not impose grantbacks to the extent that they are not very concerned about adverse selection: unlike in the case of complements, pool members owning a blocking patent can enjoy full monopoly power without joining the pool (and can actually be shown to strictly prefer not to join). Pools of complements can costlessly allow independent licensing; furthermore, if hold-up problems loom large, they prefer to impose grantbacks.

We then test these ideas using a sample of 63 patent pools established between 1895 and 2001, whose construction is described in Section 3. In the analysis in Section 4, we first examine whether pools with independent licensing are more likely to occur when patents are complementary, as the theoretical discussion suggests. To examine this, we assess whether the pool was subject to litigation for being anti-competitive and, if so, the remedies regarding licensing of intellectual property imposed in the final settlement or verdict. We acknowledge the limitations of this measure: courts have employed a variety of considerations when assessing the competitive impact of patent pools, which certainly do not correspond exactly to modern economic frameworks. It is important to note, however, that a review of judicial decisions and Department of Justice memoranda produces no evidence that the presence or absence of independent licensing and grantback provisions affects the litigation of these pools.

We first show in univariate comparisons that pools which proxies suggest were more likely to consist of substitute patents - that is, ones which were litigated or where the key patents were compulsorily licensed as part of the resolution of the case - less frequently had independent licensing provisions. This pattern also appears in regression analyses, even after controls for technology class and pool membership are added.

We then examine the utilization of grantback provisions. Pools that were not litigated are much more likely to have these provisions. There is also a positive association between grantbacks and independent licensing. Both sets of patterns are consistent with theoretical predictions. The final discussion discusses the implications of these findings and suggests some open questions. 


\section{Theoretical Perspectives}

\subsection{The Determinants of Independent Licensing}

This section derives the equilibrium co-variation between independent licensing and grantbacks. Its basic idea is that the two policies' relative costs and benefits depend on whether the pool is formed for pro- or anti-competitive reasons. A patent pool is initially formed around an initial, agreed-upon set of patents, which we will call "kernel". The model assumes that two other forms of intellectual property (IP) owned by potential pool members may later surface in relation to those contained in the kernel:

- a blocking patent, which can be thought of as a missing piece of intellectual property and is necessary to an efficient implementation of its technology. A pool member may already have knowledge leading to a blocking patent at the time the pool forms. Alternatively, it may be discovered by one of the members after the pool forms that an efficient implementation requires a missing ingredient. The key assumption is that a court cannot tell these two possibilities apart. This is clearly the case when the pool member has the knowledge, but not yet the ownership at the time the pool forms. ${ }^{2}$

- add-on innovations, which are innovations that take an individual patent in a different direction and do not enhance the value of the pool. Rather, they enable a new, stand-alone use of an individual patent. Such innovations are not affected by a grantback policy. By contrast, their benefit to the individual IP owner depends on the possibility of independent licensing. Under independent licensing, the owner of the patent and the complementary innovation is free to market the stand-alone usage as she wants; in the absence of independent licensing, though, she must bargain with the pool in order to acquire its right back.

The problem of determining when blocking patents were invented is extremely relevant in the real world not only because (as assumed above) a member may have the idea but not yet have filed an application (perhaps strategically), but also because of the process of updating patent filings often employed in the United States. In particular, firms frequently file "continuationsin-part," which allow them to add coverage of additional uses to an existing patent application.

\footnotetext{
${ }^{2}$ The other case, in which the pool member already owns or has applied for a blocking patent at the date the pool forms is also interesting, but more complex. At first sight, such hold-ups by pool members can be avoided by specifying that any blocking patent that was already the property of the member at the date of pool formation is automatically granted back to the pool. Thus, a member cannot sue the pool on the basis of a pre-pool patent: either the patent is deemed blocking by the court and then transferred to the pool for free or it is not; in either case, the pool has nothing to pay. The story becomes more intesting when the pool member may have been unaware that her patent was blocking. The court is then unable to see whether the member acted in good faith.
} 
Thus, a firm which may have made a patent application that is not blocking may have an idea as to how it can be extended to be a blocking invention. Rather than needing to file an entirely new patent application, the firm can simply file a continuation of its application with the new usage delineated. It is very difficult for outsiders to determine when exactly the insight occurred in this case.

The highly contentious litigation surrounding Rambus and the Joint Electron Devices Engineering Council ("JEDEC") standard setting organization has revolved around exactly this issue. $^{3}$ JEDEC required that its members, which included Rambus, disclose relevant patent awards and applications to avoid subsequent hold-up problems. Rambus dropped out of the JEDEC body in 1996, however, and subsequently filed continuations to its patent filings. They claimed that the new applications (which essentially blocked the dynamic semiconductor memory standard approved by JEDEC) was only conceptualized after dropping out of the standard-setting body. In 2000, Rambus filed an ultimately successful suit against Infineon, a memory manufacturer, claiming that its products made under the JEDEC SDRAM standard (as well as additional products made under the subsequent DDR SDRAM standard) infringed four Rambus patents, which were applied for between 1997 and 1999, but were continuations of a patent application originally filed in $1990 .^{4}$

The basic insight of the model is easily grasped in the polar cases of (perfect) substitutes and (perfect) complements which we develop below. Owners of substitute patents do not allow independent licensing as this would re-create competition with the pool's offering. The grantback policy choice depends on the comparison between the reduced incentive to develop patents under a grantback policy and the desire to avoid a hold-up by the owner of a blocking patent. The probability of a hold-up under substitutes is however small: the owner of a blocking patent does not need the other patents to achieve the technology's value and is a monopolist if she does not join the pool; by contrast, she would need to bargain with the pool after joining it (due to the absence of independent licensing). The owner of a blocking patent is therefore better off not joining the pool. And so the pool, if it forms, is not concerned about a potential hold-up by a member and chooses not to require grantbacks. To sum up, pools of substitutes choose no grantbacks and no independent licensing.

\footnotetext{
${ }^{3}$ For a discussion, see Rambus Inc. v. Infineon Technologies AG, et al., No. 3:00CV524, slip opinion (E.D. Va. May 2, 2001).

${ }^{4}$ This case also illustrates the difficulties of adjudicating these disputes, as alluded to in footnote 3 . Despite the fact the Rambus had also not disclosed an issued patent to JEDEC in clear violation of the policy, the centralized appellate court for patent cases overturned the sanctions imposed by the district court judge on Rambus for this behavior. In effect, the appeals court did not dispute (because the trial record is very clear on this) that Rambus tried to commit fraud, but ruled that they didn't succeed: despite Rambus' best efforts, it was, in the court's judgment, possible to comply with the standard without infringing any of the Rambus patents. (Rambus, Inc. vs. Infineon Technologies AG, et al., United States Court of Appeals for the Federal Circuit, 01-1449, -1583, -1604, -1641, 02-1174, -1192 (January 29, 2003).)
} 
Consider now the case of complements. The pool then allows independent licensing since the latter creates no competition for the pool's offering and furthermore enhances members' incentives to produce pool-unrelated innovations. The pool is also much more concerned by the hold-up problem because the (future) owner of a blocking patent cannot be a monopolist on her own and derives maximal profits when the pool includes the full kernel and therefore avoids double marginalization. Because the owners of blocking patents are not screened out, a pool of complements is much more likely to impose a grantback policy, at the cost of a reduced incentive to develop pool related innovations. This is the intuition behind the co-variation between grantbacks and independent licensing.

The model

There are $n \geq 2$ symmetric firms, each owning one patent, $i=1, \cdots, n$. For simplicity, we assume that the $n$ kernel patents are either substitutes or complements. In either case there are large gains from forming a pool: avoiding Bertrand competition when substitutes, avoiding n-marginalization when complements.

- Technology kernel. Whether complements or substitutes, the technology has the same value for consumers. Let $\mathrm{D}(\mathrm{P})$ denote the demand when the price of acquiring the technology (a single patent in the case of substitutes, the $\mathrm{n}$ patents in the case of complements) is $\mathrm{P}$. Let

$$
\mathcal{V}_{1} \equiv \max _{\mathrm{P}}\{\mathrm{PD}(\mathrm{P})\} \equiv \mathrm{P}^{\mathrm{m}} \mathrm{D}\left(\mathrm{P}^{\mathrm{m}}\right)
$$

denote the pool's profit (in the absence of blocking innovation). Let $\mathcal{V}_{0}$ denote the members's total profit on the technology kernel in the absence of a pool:

$$
V_{0}=0 \text { in the case of substitutes, }
$$

and

$$
\mathcal{V}_{0}=\mathrm{P}^{*} \mathrm{D}\left(\mathrm{P}^{*}\right) \text { in the case of complements, }
$$

where $\mathrm{P}^{*}>\mathrm{P}^{\mathrm{m}}$ is given by individual profit maximization:

$$
\frac{\mathrm{P}^{*}}{\mathrm{n}} \mathrm{D}^{\prime}\left(\mathrm{P}^{*}\right)+\mathrm{D}\left(\mathrm{P}^{*}\right)=0,
$$

while

$$
\mathrm{P}^{\mathrm{m}} \mathrm{D}^{\prime}\left(\mathrm{P}^{\mathrm{m}}\right)+\mathrm{D}\left(\mathrm{P}^{\mathrm{m}}\right)=0 .
$$


- Blocking patent: There is either a (single) blocking patent or none. If there is one, each firm is equally likely to have it. With probability $x$, one of the firms ${ }^{5}$ has before the pool forms (knowledge for) a blocking innovation. ${ }^{6}$ With probability $y$, the existence of a missing and blocking piece of intellectual property is revealed after the pool forms to one of the members (with probability $y / n$ each) who can then spend $\gamma>0$ in order to develop and patent it. With probability $1-x-y$, the kernel technology is complete (unblocked). Consider the beliefs of a prospective member who does not own a blocking piece of intellectual property before the pool forms: Let

$$
\rho \equiv \frac{\frac{n-1}{n} x}{1-\frac{x}{n}}
$$

denote the probability that another member already has a blocking patent, and

$$
\mu \equiv \frac{y}{1-\frac{x}{n}}
$$

denote the probability that a blocking patent will arise after the pool forms.

Because the patent is blocking, the technology described by the kernel is worthless unless a license to the blocking patent is secured.

- Add-on innovations: As discussed earlier, each firm can also take its patent-specific knowledge in another direction: Firm $i$ can develop a stand-alone use for patent $i$. This stand-alone use is unrelated to the field of use associated with the technology covered by the kernel. ${ }^{7}$ A firm's investment in creating a stand-alone use costs $\mathrm{c}>0$ and yields revenue $\delta$ where:

Assumption 1: $\mathrm{g} \equiv \delta-\mathrm{c}>0>\frac{\delta}{2}-\mathrm{c}$.

The first inequality implies that the firm invests and makes a positive profit if it keeps ownership of the patent (either it does not join the pool or it has independent licensing rights). The second inequality will imply that if it has to secure back the ownership by bargaining "à la Nash" with the pool, then it will not invest in developing a stand-alone use. [The result would a fortiori hold if securing a stand-alone license from the pool were infeasible.] This assumption more generally captures the idea that ownership raises the incentive for investment, and it generates a benefit of independent licensing. Let $\mathrm{G} \equiv \mathbf{n g}$.

We make two further assumptions:

\footnotetext{
${ }^{5}$ Alternatively, one could assume that the firm already owns a blocking patent. The theory is then more complex, as a grantback policy that covers only IP that can be proved to have existed at the date of pool formation presents holdups without inhibiting post-pool formation innovation. The cost of a grantback policy must then be traced to the members' concern that some of their patents be unduly assessed essential later on.

${ }^{6}$ There is no loss of generality in assuming that if it exists, then it belongs to a pool member. Otherwise the choice of grantback policy is irrelevant.

${ }^{7}$ In particular, these stand-alone uses are not blocked by the pool-blocking innovation, if any.
} 
Assumption 2: $\frac{v_{1}}{2}>\gamma>\frac{v_{1}}{2 n}$.

This assumption will guarantee that, under Nash bargaining, a third party will benefit from blocking the patent pool, and that a member will not produce the blocking patent if she must grant it back to the pool.

Assumption 3: $\rho \frac{\nu_{1}}{2} \geq \mu\left(\frac{V_{1}}{2}-\gamma\right)$.

This assumption, as we will see, requires that adverse selection at the contracting stage is nonnegligible. Were this assumption violated, grantbacks would never be optimal.

The timing goes as follows:

Stage 0: The $\mathfrak{n}$ firms are endowed with one of the kernel patents each. One of the $\mathfrak{n}$ firms may further have knowledge for a blocking innovation.

Stage 1: Firms individually decide whether to join the pool. We assume that the pool does not form if a potential member refuses to join (this assumption is not crucial: see below). Members are entitled to equal shares of future profits of the pool.

Members then choose (a) whether independent licenses are allowed and (b) whether grantbacks are required. Members vote on this and so the choice is made so as to maximize the welfare of members without blocking patent, that is of all, or all but one, members depending on the circumstances. ${ }^{8}$

Stage 2: Firms non-cooperatively choose whether to invest in add-on innovations. A firm that has invested must then secure a license from the pool if independent licensing is prohibited $;^{9}$ it markets its add-on innovation to end users.

Provided that there was no blocking patent at stage 0 , there is still a possibility of a missing piece of intellectual property that needs to be developed to implement the technology. In this case, with probability $1 / n$ each member gets a chance to develop (at private cost $\gamma$ ) and patent it.

Stage 3: If there was scope for a pool-related innovation at stage 2 and the member who had the opportunity to develop it did not seize it, a third party develops this innovation and obtains a patent (see Assumption 2).

The pool, if it has formed at stage 1, bargains over the license of the blocking innovation, if any (of course, under a grantback policy, there is no bargaining if the blocking innovation is held by a member).

\footnotetext{
${ }^{8}$ In the latter case, the owner of the blocking patent cannot alter the majority's vote and might as well vote like the majority.

${ }^{9}$ Note that we here focus on "ex post licensing," i.e. licensing by the pool after firms choose their investments. "Ex ante licensing" is of course equivalent to independent licensing.
} 
Stage 4: The kernel technology is licensed: non-cooperatively at price $\mathrm{P}^{*}$ in the absence of a pool, cooperatively at the profit-maximizing price $\mathrm{P}^{\mathrm{m}}$ if a pool has formed.

Finally, we assume that bargaining, if any, is "Nash bargaining."

Proposition 1 Under Assumptions 1 through 3, the following constitutes the unique equilibrium:

(i) Under complements, the pool always forms and chooses to require grantbacks and to allow independent licensing.

(ii) Under substitutes, the pool forms if and only if there is no blocking patent. The pool does not require grantbacks but does not allow independent licensing.

\section{Proof of Proposition 1}

Complements. Let us first show that in the case of complements, the equilibrium has all firms (including the one with a blocking patent, if any) join the pool and the pool allow independent licensing and impose grantbacks. That the pool allows independent licensing is obvious: Independent licenses never compete with the pool's offering and encourage the members to invest in add-on innovations. And so, allowing independent licenses results in an extra profit equal to $\mathrm{g}$ per firm relative to what they gain from the pool.

Under grantbacks, the pool members' total profit (divided equally, because the only possible difference among members — the ex ante existence of a blocking patent — is irrelevant under a grantback policy) is

$$
(1-\mu) \nu_{1}+\mu \frac{V_{1}}{2}+G
$$

With probability $1-\mu$, there is no blocking patent (probability $1-\mu-\rho$ ) or else it is handed over for free to the pool (probability $\rho$ ). The pool then makes profit $\nu_{1}$. With probability $\mu$, the opportunity to develop a blocking patent arises ex post, but the pool member who can seize this opportunity does not. Seizing this opportunity involves private cost $\gamma$ and increases the pool's profit from $V_{1} / 2$ (the profit that results from Nash bargaining between the pool and the third party who patents the blocking innovation at stage 3) to $\mathcal{V}_{1}$. The pool member receives only $1 / n$ of this increase. The right-hand inequality in Assumption 2 implies that the pool member's behavior is indeed optimal.

In the absence of a grantback policy, by contrast, the expected profit of a pool member without blocking patent is $(1 / \mathrm{n}$ times $)$ :

$$
(1-\rho-\mu) \mathcal{V}_{1}+\mu\left(\mathcal{V}_{1}-\gamma\right)+\rho \frac{\mathcal{V}_{1}}{2}+\mathrm{G} .
$$

That is, with probability $\mu$, the member who has the opportunity to develop the blocking innovation does so (since $\left.\mathcal{V}_{1} / 2>\gamma\right)$; members hold up the pool, but this is a wash in expectation. 
With probability $\rho$, however, one of the members holds up the others and gets half of the profits.

Thus, a grantback policy is optimal if and only if:

$$
\rho \frac{V_{1}}{2} \geq \mu\left(\frac{V_{1}}{2}-\gamma\right),
$$

that is under Assumption 3.

Finally, we must check that the holder of a blocking patent wants to join the pool at stage 1. By not joining, she gets $V_{0} / n+g$ since having two essential innovations is no better in the market place than owning a single one. By joining, she gets $V_{1} / n+g>V_{0} / n+g$. [Note that these computations rely on the assumption that the pool does not form later on. She would be indifferent if the pool did form later on. Any delay in forming the pool in practice would reduce sales or delay the investments of pool users and would result in a strict preference for joining the pool.]

Substitutes. Let us show that the following is the only equilibrium:

(i) The owner of a blocking patent does not join the pool (and so the pool forms only if there is no blocking patent at stage 0$)$.

(ii) If the pool forms, then the members vote for no independent licensing and no grantback.

To show part (i), note that the owner of a blocking patent is a monopolist on the kernel technology when not joining the pool. The owner then obtains $\mathcal{V}_{1}+\mathrm{g}$. If she joins the pools, she must bargain with the pool (since she no longer has a license to her own patent) and gets $\mathcal{V}_{1} / 2$ only. [Assumption 1 implies that there is no add-on.]

\section{Constructing the Sample}

We now seek to test these ideas. This section describes how we created the sample used in the analysis.

The empirical literature on patent pools to date - which, as noted above, has been mainly confined to law reviews - largely focuses on the reported judicial decisions on these arrangements. While the decisions discuss aspects of the pools' rules concerning the licensing of intellectual property, they do not provide sufficient detail to allow a systematic analysis of the features of the pools. In order to test the theory delineated above, we need the actual agreements governing the patent pools. This section describes the procedure we employed to construct the patent pool sample, as well as the supplemental data used in the analysis. 


\subsection{Identifying the Pools}

The first question was one of definition. We define these as cases where either (a) two or more firms combine to license patents to third parties (which we tern "open" pools), or (b) three or more firms come together to license patents to share the patents among themselves ("closed" pools), or both. This definition excludes several other types of arrangements:

- Simple cross-license arrangements between two firms, where there was no clearly stated intention of engaging in future licensing transactions.

- New operating companies that were established to manufacture products based on intellectual property of a number of firms (e.g., Radio Corporation of America).

- Firms that acquired large amounts of patents and then licensed them to other concerns (e.g., American Steel and Wire Company, American Tobacco Company, and other "patent consolidators").

- Pools that are dominated by non-profit entities (e.g., universities), where profit-maximizing considerations may not be paramount. ${ }^{10}$

We then compiled a list of all identifiable patent pools. The primary sources for these identifications were Carlson [1999], Commerce Clearing House [various years], Kaysen and Turner [1959], Merges [1999], Vaughn [1925, 1956], and "War and Peace" [1942], though many other sources were used as well. In total, we identified approximately 125 patent pools, dating between 1856 and 2001.

These pools appear not to have been disclosed by firms in filings with the U.S. Securities and Exchange Commission. Instead, we obtained the pooling agreements in five ways:

- Congressional hearings during the 1930s and 1940s scrutinized a number of patent pools (especially U.S. Congress [1938-1940], U.S. House [1935], U.S. Senate [1942]). In many cases, the pooling agreements were either published in the records of the hearings or else retained as unpublished exhibits (which are preserved in the committees' files in the National Archives in Washington, D.C.)

- Many of the pools were subjects of private or federal antitrust litigation. In the course of the trials, frequently the patent pooling agreements were entered as exhibits. The dockets

\footnotetext{
${ }^{10}$ Under the Bayh-Dole Act of 1980 and its enabling legislation, research institutions are subject to a variety of constraints when licensing federally funded technologies, such as the requirement that they give preference to small businesses and the threat of the government exercising its "march-in rights" if the invention is not being commercialized in a timely manner.
} 
of these cases are preserved in the various regional depositories of the National Archives. In order to limit costs, we focused on those depositories with the greatest concentration of cases: Boston (which has records from federal district cases in the first judicial circuit), Chicago (which includes much of the sixth and seventh circuits, as well as some of the ninth circuit), Kansas City (which has records from parts of the eighth and tenth circuits, as well as older records from parts of the second and third circuit), and New York City (which has more recent records from parts of the second and third circuits).

- The Antitrust Division of U.S. Department of Justice investigated a number of patent pools, some of which were litigated against and others were not. Since the time these files were used by Hay and Kelley [1974], the records have been transferred to the National Archives' Suitland, Maryland facility. These files were located with the assistance of Johnson [1981]. As part of the investigations, the patent pooling agreements were sometimes gathered and preserved.

- The U.S. Department of Justice and the U.S. Federal Trade Commission have scrutinized a number of the recent pools. In these cases, we obtained the key documents through Freedom of Information Act requests.

- In the case of recent pools that had not been the subject of federal scrutiny, we requested the documents from the pool administrators.

In all, we were able to collect the documentation on 63 patent pools established between 1895 and 2001. ${ }^{11}$ We then identified and coded the key characteristics of the agreements. We focused on the initial agreement establishing the pool, rather than the many amendments that frequently characterize these agreements.

Given the lack of a systematized database of patent pools, it is difficult to assess the comprehensiveness of our sample. At the same time, it is reassuring that the distribution of the 63 pools, summarized in Table 1, reflects accounts of the history of patent pools (see Carlson [1999], Merges [1999], and Vaughn [1925, 1956]). The first patent pool is widely agreed to have been established by sewing machine manufacturers in 1856. By the 1890s, pooling agreements had become commonplace in the United States. Interest in patent pools stemmed in part from the desire to avoid the restrictions on anti-competitive activities that had been enacted as part of the Sherman Act of 1890. Patent pools were seen as exempt from regulatory scrutiny, a perception that was buttressed in 1902 when the U.S. Supreme Court refused to invalidate a patent pool,

\footnotetext{
${ }^{11}$ We have not identified any non-U.S. government sources for patent pool agreements (though our sample does include some agreements exclusively between firms outside the United States). Antitrust authorities outside the U.S. historically do not appear to have systematically reviewed or litigated patent pooling arrangements until recent years.
} 
noting "the general rule is absolute freedom in the use or sale of patent rights under the patent laws of the United States. The very object of these laws is monopoly...."12

Soon thereafter, however, the tide began to shift. The Supreme Court struck down the bathtub enameling patent pool in 1912 in the Standard Sanitary decision. Private antitrust litigation regarding pools increased sharply thereafter. Government efforts to investigate and break up pools accelerated after well-publicized hearings on patent pools in the late 1930s. The Supreme Court decision in the Hartford-Empire case, in which Justice Hugo Black pronounced "the history of this country has perhaps never witnessed a more completely successful economic tyranny over any field of industry than that accomplished by [the pool members]," ${ }^{13}$ was widely seen as ushering in an era of regulatory intolerance for these arrangements. As a consequence, the number of new patent pools formed in the United States dwindled away to almost nothing after World War II.

In 1995, however, the U.S. Department of Justice and U.S. Federal Trade Commission issued its "Antitrust Guidelines for the Licensing of Intellectual Property," which explicitly noted, "cross-licensing and pooling arrangements may provide pro-competitive benefits." 14 Shortly thereafter, Justice's Antitrust Division issued a favorable review letter concerning the MPEG-2 Video patent pool. The result has been a modest resurgence of these arrangements.

We believe it is likely that the sample underrepresents the very oldest pools: the federal government was far less active in antitrust enforcement during this period, and while private suits were filed, many of district court files from this period are lost or unusable. In addition, to dissolving the pool, in many cases the parties were required to license the intellectual property that had been included in the collaboration. In our analysis, we will focus on how the final ruling and settlement treated the intellectual property in the pool. It may be that pools involving German firms are disproportionately represented, since ties between German and American firms were a particular focus of the Bone Committee's hearings in 1942.

\subsection{Identifying Pools of Complements and Substitutes}

In the theoretical discussion above, we distinguish between pools consisting of patents which are substitutes or complements: that is, between pools where the motivation is to avoid Bertrand competition between licensees and those where the goal is to avoid the familiar problem of each party demanding too high a licensing rate (Shapiro [2000]). We seek to relate the nature of the intellectual property in the pool to its rules regarding licensing.

Of course, such pools do not come clearly labeled in the real world as consisting of comple-

\footnotetext{
${ }^{12}$ E. Bement \& Sons v. National Harrow Company, 186 U.S. 70, 91 (1902).

${ }^{13}$ Hartford Empire Co. v. U.S., 323 U.S. 386, 436-437 (1945).

${ }^{14}$ http://www.usdoj.gov/atr/public/guidelines/ipguide.htm (accessed March 19, 2002).
} 
mentary or substitute patents. Thus, we must employ proxies based on any litigation concerning the pool to identify such awards.

Over the entire period under study, pools have been challenged by private parties for being anti-competitive. For almost the entire time span, the Federal government has intervened in challenging pools they believe to be anti-competitive. Thus, the extent and outcomes of the litigation involving the pool may be a reasonable indication of the intentions of the pool founders.

This is, to be sure, an imperfect proxy. A variety of criterion weighted into the assessment of patent pools in the pre-1995 era, which only imperfectly map into modern economic criteria for assessing patent pools. In particular, as Gilbert [2004] highlights, in many instances, considerations as to whether the patents in the pool were complementary or not only sometimes were the critical consideration in the courts' judgments. In many cases, the courts appear to have focused on the intents of parties entering into the pool, and the extent to which pool members strove to control pricing of the products in the industry through price floors or royalty requirements. Another major concern of the courts was the extent to which the pool was open to additional parties who might wish to join, or was closed to new members.

In order to understand the motivations for the government commencing litigation against pools, we reviewed all available memoranda on these pools from the U.S. Department of Justice and the verdicts in these 63 cases. While many considerations are highlighted, including the pricing and rebate schemes employed by the pool members, the history of patent litigation commenced by pool members, and the rules concerning pool membership, the aspects of licensing practice that we are focusing on here - the presence of independent licensing and grantback provisions - appear to have not directly impacted the decision to litigate patent pools or the verdicts in these cases. A review of these cases fails to turn up any mention of the these practices prior to the 1997 Department of Justice review of the MPEG-2 pool, where the desirability of independent licensing provisions appears to have been first articulated. As Robert Merges noted, "within the Department of Justice, pools were historically modeled strictly as horizontal entities - basically, cartels until proven innocent." As a result, the presence of independent licensing or grantback provisions apparently did not directly impact the decision to litigate pools. ${ }^{15}$

We anticipate that pools that were formed with substitute patents and the goal of dampening competition between licensees will be more likely to be litigated. We seek to identify any litigation involving the pool and its outcome, relying upon the searches of reported decisions and docket files (see the description above), the files of the U.S. Department of Justice (see above), Commerce Clearing House's Trade Regulation Reporter (which reports the terms of many settlements of these cases), and media and historical accounts of any litigation involving these pools.

\footnotetext{
${ }^{15}$ The comment from Merges was from e-mail correspondence. As a diagnostic check, we repeat the analyses below excluding pools formed in 1997 and after, and find that the results are little changed.
} 
Table 2 summarizes the outcome of these cases. The first tabulation indicates that in $28 \%$ of the pools, there was no litigation, and in about one-tenth of the instances, the litigation was dropped without a ruling or settlement. In $38 \%$ of the pools, the case was settled or a consent decree signed prior to a judicial verdict. The remaining pools were litigated at least to a district court verdict.

The second tabulation indicates the outcome of the case, conditional on the pool having been litigated at least to a settlement or a judicial ruling. First, in almost all instances where the case was not dismissed outright, the pool itself was dissolved. In addition, there were also often remedies regarding the intellectual property in the pool. In our analysis, we will focus on how the intellectual property was handled. The remedies included (listed in the order of the strictness of the remedy) required renegotiation of existing licenses, mandatory licensing to third parties on reasonable and non-discriminatory (RAND) terms, and mandatory licensing to third parties on a royalty free basis.

\section{Analysis}

We proceed in two parts. First, we examine provisions around independent licensing of pool members. We then turn to considering the employment of grantback provisions.

\subsection{Analyses of Independent Licensing}

We begin by examining whether pools with independent licensing are more likely to occur in pools with complementary patents, as the theoretical discussion above suggests. We examine this question using unviariate and regression analyses.

In Table 3, we undertake two sets of comparisons. First, we divide the observations by our proxies for the degree of substitutability of the patents in the pools based on the extent of litigation and the nature of the remedies. For each subset, we look at the percentage of the pools had independent licensing provisions.

We find in each case that patents which were more likely to have complementary patentsthat is, pools that were not litigated or fared better in litigation-were more likely to have independent licensing. These differences are often statistically significant. When divided by the various proxies for the degree of substitutability in the pools, in three out of five cases the differences in the use of independent licensing were significant at the five-percent confidence level.

We also divide the observations by whether there was independent licensing or not, and examine the extent to which the proxies for complementary patents differ. For this analysis, we create indexes for how the case was resolved and the type of remedy employed. Table 3 indicates 
that the two resolution scores are different with a high degree of statistical significance: if there is no independent licensing provision, the case is much more likely to have been litigated to a settlement or a verdict, and the verdict is more likely to have restrictive provisions concerning licensing.

We then turn to examining these changes in a logit regression framework. We employ as the dependent variable a dummy indicating whether the pool had independent licensing. When we examine the proxies for substitutability, a clear pattern emerges: the further the litigation involving the pool progressed, or the more draconian the remedy that was ultimately imposed regarding licensing of the pool's patents, the less likely is the pool to have an independent licensing provision. These patterns continue to hold when we employ controls for the technology class for the pool and the number of members in the pool. ${ }^{16}$

\subsection{Analyses of Grantback Provisions}

We now turn to considering the use of grantback provisions, which require firms to license related intellectual property to the pool. The theoretical discussion above suggested that grantbacks and independent licensing should be strongly associated with pools formed of complementary patents.

Table 5 presents some tabulations of the use of grantbacks. Once again, we use the extent to which the pool was litigated as a proxy for the nature of the patents in the pool. Pools that were not litigated are much more likely to require grantbacks. This difference is statistically significant at the five-percent confidence level. When no remedy involving mandatory third-party licensing was imposed, there is a somewhat greater (but not a statistically significant) probability that grantbacks were used. Finally, we show that grantbacks are more positively associated with independent licensing, when the pool is not litigated or is subject to less strict remedies regarding licensing. These results are consistent with theoretical suggestions.

We then examine these patterns in a regression analysis. We again use a logit specification, with a dummy variable denoting a pool that required grantbacks as the dependent variable.

Table 6 reports the results:

- In the first four regressions, we employ the two proxies for pools consisting of complemen-

\footnotetext{
${ }^{16}$ It might be thought that pools with many entities would be more likely to have provisions for independent licensing. If a large number of parties are included in the pool, licensors are only likely to be interested in a patents held by a subset of firms. Independent licensing allows this problem to be addressed. To be sure, pools do not need to allow independent licensing in order to let licensors select which patents meet their needs. Alternatively, they could offer "menus," or subsets of patents to license. One of the surprises we encountered in the data collection phase was how few pools (11\% of the entire sample) offered menus. In discussions with practitioners, transaction costs, disagreements over how to price items on the menu, and disputes over the sharing of licensing fees are all highlighted as reasons discouraging the use of menus. Such potential disagreements may make independent licensing an attractive substitute for menus. (The results are also robust when we employ the number of patents in the pool as a control variable.)
} 
tary patents. The results are similar to those in the cross-tabulations above. Pools that are not litigated are strongly associated with the use of grantbacks. The independent variable denoting pools that do not see the imposition of mandatory third-party licenses to the pool's patents takes on the expected positive sign, but is not statistically significant.

- We use as an independent variable in the next two regressions an indicator denoting pools that allow independent licensing. There is no clear relationship between independent licensing and grantbacks: no results are even close to being statistically significant.

- In the last four regressions, we employ an interaction between the proxies for pools consisting of complementary patents and the dummy for independent licensing. The coefficient of interaction term is consistently positive and statistically significant. Patents that are likely to have complementary patents also tend to offer grantbacks, but only if independent licensing is also present. This result is consistent with the suggestion that these two features of pool licensing policy should co-vary.

\section{Conclusions}

This paper empirically examines the licensing rules associated with patent pools. These complex organizations have been little studied, despite their inherent interest on both theoretical and practical grounds.

The paper focuses on two critical features of licenses offered in patent pools: independent licenses and grantback requirements. The model posits a cost and a benefit for both of these tools, which leads to two predictions. First, pools consisting of complementary patents should be more likely to allow members to engage in independent licensing. Second, grantbacks should be associated with pools of complementary patents, and with those that allow independent licensing. We then examine this prediction using a sample of 63 patent pools established between 1895 and 2001. We find results that are generally consistent with the theoretical predictions.

At the same time, we are aware of important limitations to our analysis. For instance, our conversations with participants in the MPEG-2 (a digital video compression standard used in products including DVD and high definition television) patent pool highlighted some issues that we did not address here, including the determinants of the sharing rules between pool participants when patents are of differing value. Similarly, the relationship between patent pools and the standardization process is a complex and poorly understood one: recent pools invariably have been formed in conjunction with the adoption of a technological specification by a standardsetting organization. These and related questions surely deserve exploration. 


\section{References}

[1] Aoki, Reiko, and Sadao Nagaoka, "Coalition Formation for a Consortium Standard Through a Standard body and. a Patent Pool: Theory and Evidence from MPEG2, DVD, and 3G," Hitotsubashi University Institute of Innovation Research Working Paper WP\#05-01, 2005

[2] Bittlingmayer, George L., "Property Rights, Progress, and the Aircraft Patent Agreement," Journal of Law and Economics, 31 (1988), 227-248.

[3] Carlson, Steven C., "Patent Pools and the Antitrust Dilemma," Yale Journal on Regulation, 16 (1999), 359-399.

[4] Cassady, Ralph, Jr., "Monopoly in Motion Picture Production and Distribution, 1908-1915," Southern California Law Review, 32 (1959), 325-390.

[5] Clark, Jeanne, Joe Piccolo, Brian Stanton, and Karin Tyson, "Patent Pools: A Solution to the Problem of Access in Biotechnology Patents?," Unpublished working paper, U.S. Department of Commerce, Patent and Trademark Office, 2001.

[6] Clarkson, Gavin, "Patent Network Density: The Quest for Patent Thickets," Unpublished working paper, Harvard University, 2003.

[7] Commerce Clearing House, Trade Regulation Reporter, New York, Commerce Clearing House, various years.

[8] Gallini, Nancy T., "The Economics of Patents: Lessons from Recent U.S. Patent Reform," Journal of Economic Perspectives, 16 (Spring 2002), 131-154.

[9] Gilbert, Richard J., "Antitrust for Patent Pools: A Century of Policy Evolution," Stanford Technology Law Review, (2004) 3, http://stlr.stanford.edu/STLR/Articles/04_STLR_3.

[10] Hay, George A., and Daniel Kelley, "An Empirical Study of Price Fixing Conspiracies," Journal of Law and Economics, 17 (1974), 13-38.

[11] Johnson, Marion, Preliminary Inventory of the General Records of the Department of Justice, Washington, National Archives and Records Administration, 1981.

[12] Kaysen, Carl, and Donald Turner, Antitrust Policy: An Economic and Legal Analysis, Cambridge, Harvard University Press, 1959.

[13] Lerner, Josh, and Jean Tirole, "Efficient Patent Pools," American Economic Review, 94 (2004), 691-711. 
[14] Merges, Robert P., "Institutions for Intellectual Property Transactions: The Case of Patent Pools," Unpublished working paper, University of California at Berkeley, 1999.

[15] Priest, George L., "Cartels and Patent Licensing Arrangements," Journal of Law and Economics, 20 (1977), 309-377.

[16] Shapiro, Carl, "Navigating the Patent Thicket: Cross Licenses, Patent Pools, and Standard Setting," Innovation Policy and the Economy, 1 (2000), 119-150.

[17] U.S. Congress, Temporary National Economic Commission on Public Resolution 113, Investigation of Concentration of Economic Power: Hearings, 75th-76th Congress, Washington, U.S. Government Printing Office, 1938-1940.

[18] U.S. House of Representatives, Committee on Patents, Pooling of Patents, 74th Congress, 4 volumes, Washington, Government Printing Office, 1935.

[19] U.S. Senate, Committee on Patents, Patents, 77th Congress, 2nd session, Washington, Government Printing Office, 1942.

[20] Vaughan, Floyd A., The Economics of Our Patent System, New York, MacMillan, 1925.

[21] Vaughan, Floyd A., The United States Patent System: Legal and Economic Conflicts in American Economic History, Norman, University of Oklahoma Press, 1956.

[22] "War and Peace and the Patent System," Fortune, 26 (August 1942), 102-105, 132, 134, 136, 138, 141. 
Table 1: The sample of patent pools. The table presents information on the 63 pools analyzed in the paper, including the year in which the pool was formed, the Standard Industrial Classification (SIC) that most closely describes the pool's subject matter, the number of members initially included in the pool, the nationalities of the entities initially in the pool, and the manner in which the pool agreement(s) were located.

\begin{tabular}{|c|c|c|c|c|c|}
\hline Pool Subject Matter & $\begin{array}{c}\text { Year of } \\
\text { Formation }\end{array}$ & $\begin{array}{c}\text { Closest } \\
\text { SIC Code }\end{array}$ & $\begin{array}{l}\text { Initial Pool } \\
\text { Membership }\end{array}$ & $\begin{array}{c}\text { Nations } \\
\text { Represented }\end{array}$ & $\begin{array}{l}\text { Source of } \\
\text { Contract }\end{array}$ \\
\hline Pneumatic Straw Stackers & 1895 & 3523 & 3 & U.S. & NAR \\
\hline Duplicating Machines & 1912 & 3579 & 2 & U.S. & NAR \\
\hline Automobiles & 1915 & 3711 & 146 & U.S. & USC \\
\hline Railroad Couplers & 1916 & 3743 & 6 & U.S. & NAR \\
\hline Aircraft & 1917 & 3721 & 8 & U.S. & USC \\
\hline Braking Systems & 1924 & 3714 & 2 & U.S. & NAR \\
\hline Plate Glass & 1924 & 3211 & 4 & U.S. & NAR \\
\hline Sand-Spun Pipe & 1924 & 3321 & 7 & U.S. & NADC \\
\hline Dyestuffs & 1925 & 2865 & 11 & Ger.; U.S. & USC \\
\hline Magnesium & 1927 & 3339 & 2 & U.S. & USC \\
\hline Metal Dies & 1928 & 3544 & 2 & Ger.; U.S. & USC \\
\hline Cast Iron Pipe & 1929 & 3321 & 4 & U.S. & NADC \\
\hline Coated Abrasives & 1929 & 3291 & 9 & U.S. & NAR \\
\hline Petroleum Refining-JASCO & 1929 & 2911 & 4 & Ger.; U.S. & USC \\
\hline Petroleum Refining-Hydro Patents & 1930 & 2911 & 4 & Ger.; U.S. & USC \\
\hline Water Conditioning Apparatus & 1930 & 3589 & 3 & Ger.; U.K.; U.S. & NAR \\
\hline Grinding Hobs & 1931 & 3545 & 3 & U.S. & NAR \\
\hline Magnesium Alloys & 1931 & 3339 & 2 & Ger.; U.S. & USC \\
\hline Rail Joint Bars & 1931 & 3312 & 3 & U.S. & NAR \\
\hline Railroad Springs & 1932 & 3493 & 3 & U.S. & NAR \\
\hline Hydraulic Oil Pumps & 1933 & 3561 & 3 & U.S. & NADC \\
\hline Machine Tools & 1933 & 3541 & 4 & U.S. & NAR \\
\hline Petroleum Refining-Gray Processes Co. & 1933 & 2911 & 5 & U.S. & USC \\
\hline Petroleum Refining-JUIK Group & 1933 & 2911 & 5 & U.S. & USC \\
\hline Phillips Screws & 1933 & 3452 & 2 & U.S. & NAR \\
\hline Television/Radio Apparatus-Australia & 1933 & 3651 & 2 & Australia & NAR \\
\hline Beryllium & 1934 & 3339 & 3 & Ger.; U.S. & USC \\
\hline Electrical Equipment & 1934 & 3600 & 3 & Ger.; U.S. & NAR \\
\hline Lecithin & 1934 & 2070 & 5 & Den.; Ger.; U.S. & NAR \\
\hline Petroleum Refining-Fractional Distillation & 1934 & 2911 & 5 & U.S. & USC \\
\hline Polymeric Acrylic Acid & 1934 & 2821 & 2 & Ger.; U.S. & USC \\
\hline Variable Condensers & 1934 & 3629 & 3 & U.S. & NAR \\
\hline Acrylic Acid For Laminated Glass (Plexigum) & 1935 & 3229 & 2 & U.S. & NAR \\
\hline Dyestuffs & 1935 & 2865 & 5 & Switz.; U.S. & USC \\
\hline Petroleum Refining-Gas Polymerization & 1935 & 2911 & 5 & U.S. & USC \\
\hline
\end{tabular}




\begin{tabular}{|c|c|c|c|c|c|}
\hline General Chemical & 1936 & 2800 & 3 & Can.; U.K.; U.S. & USC \\
\hline Male Hormones & 1937 & 2833 & 4 & Ger.; Switz.; U.S. & NAR \\
\hline Wrinkle Finishes & 1937 & 3582 & 2 & U.S. & NAR \\
\hline Dropout Cutouts & 1938 & 3643 & 2 & U.S. & NAR \\
\hline Inductive Heat Treatment & 1938 & 3547 & 2 & U.S. & NAR \\
\hline Opthalmic Frames & 1938 & 3851 & 2 & U.S. & NAR \\
\hline Petroleum Refining-Hydrocarbon & 1938 & 2911 & 5 & Ger.; U.S. & USC \\
\hline Pour Depressants & 1938 & 2911 & 3 & U.S. & NAR \\
\hline Slip Covers & 1938 & 2221 & 3 & U.S. & NADC \\
\hline Petroleum Refining-Alkylation & 1939 & 2911 & 4 & U.K.; U.S. & USC \\
\hline Dyestuffs & 1940 & 2865 & 3 & U.K.; U.S. & USC \\
\hline Television Equipment & 1942 & 3651 & 3 & U.S. & NAR \\
\hline Television/Radio Apparatus-Canada & 1943 & 3651 & 4 & Can.; U.S. & NAR \\
\hline Alginate (Dental) Impression Powder & 1947 & 3843 & 3 & U.S. & NADC \\
\hline Plastic Artificial Eyes & 1948 & 3842 & 2 & U.S. & NAR \\
\hline Television/Radio Apparatus-Great Britain & 1948 & 3651 & 5 & Neth.; U.K. & NAR \\
\hline Tractor Cabs & 1948 & 3537 & 3 & U.S. & NAR \\
\hline Daylight Fluorescent Pigments & 1949 & 2816 & 4 & U.S. & NADC \\
\hline Glass Fibers & 1956 & 3229 & 3 & Jap.; U.S. & NAR \\
\hline Sewing Machines & 1956 & 3639 & 3 & It.; Swed.; U.S. & NAR \\
\hline Laser Eye Surgery & 1992 & 3845 & 2 & U.S. & FTCFOIA \\
\hline MPEG-2 Digital Video & 1997 & 3652 & 8 & Jap.; Neth.; U.S. & DOJFOIA \\
\hline DVD-ROM, DVD-Video & 1998 & 3652 & 3 & Jap.; Neth. & DOJFOIA \\
\hline Wireless Personal Area Networking-Bluetooth & 1998 & 3663 & 9 & Fin.; Jap.; Swed.; U.S. & POOL \\
\hline 1394 Digital Data Transfer Interface & 1999 & 3577 & 6 & Japan; Neth.; U.S. & POOL \\
\hline DVB-T - Digital Broadcasting & 1999 & 3663 & 4 & Fr.; Jap.; Neth. & POOL \\
\hline DVD-ROM, DVD-Video & 1999 & 3652 & 6 & Jap.; U.S. & DOJFOIA \\
\hline 3G-Mobile Communications & 2001 & 3663 & 19 & Fin.; Fr.; Ger.; It.; Jap.; Neth.; S.K. & POOL \\
\hline
\end{tabular}

Notes: Standard Industrial Codes ending with one or more zeros indicate that the pool covered multiple subclasses within a given classification.

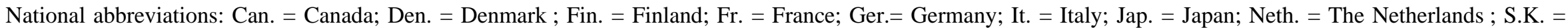
South Korea; Swed. = Sweden; Switz. = Switzerland; U.K. = United Kingdom ; U.S. = United States.

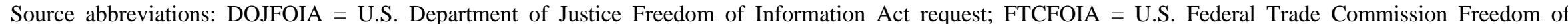

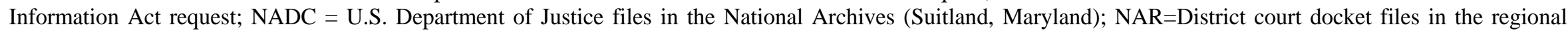

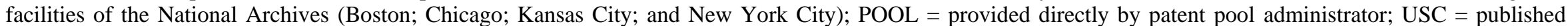
hearings or unpublished files of the U.S. congressional investigations. 
Table 2: Summary Statistics on Pool Litigation Outcomes

\begin{tabular}{|c|c|c|c|}
\hline \multicolumn{2}{|c|}{$\underline{\text { Resolution of Case* }}$} & \multicolumn{2}{|c|}{$\underline{\text { Remedy (Conditional on Pool Being Litigated to Ruling or Settlement)** }}$} \\
\hline Not Litigated & $28 \%$ & Case Dismissed & $10 \%$ \\
\hline Suit Dropped & $8 \%$ & Licensing-Related Remedies: & \\
\hline Settlement or Consent Decree & $38 \%$ & Renegotiation of Existing Licenses & $16 \%$ \\
\hline District-Level Judicial Decision & $13 \%$ & Mandatory Cross-Licensing among Pool Members & $5 \%$ \\
\hline \multirow[t]{7}{*}{ Appellate Decision } & $14 \%$ & Mandatory RAND 3rd-Party Licensing & $63 \%$ \\
\hline & & Mandatory Royalty-Free 3rd-Party Licensing & $39 \%$ \\
\hline & & Other Remedies: & \\
\hline & & Pool Dissolved & $82 \%$ \\
\hline & & Restrictions on Future Patent Litigation & $18 \%$ \\
\hline & & Fine & $21 \%$ \\
\hline & & Other & $74 \%$ \\
\hline
\end{tabular}

Notes

*"Resolution of Case" reports the furthest point reached in the litigation.

**"Remedy" includes multiple remedies for many cases. 
Table 3: Cross-Tabulations of Outcomes and Independent Licensing Provision

Overall Sample

Was Pool Litigated?

Was Pool Litigated to Ruling or Settlement?

Were Licensing Terms Changed?

Was New 3rd-Party Licensing Added?

Was New Royalty-Free 3rd-Party Licensing Added?

Mean of Resolution Score*

Mean of Licensing Remedy Score**

Mean of Count of Pool Members
Percent of Pools with Independent Licensing

Yes

No

Chi-square

p-Value

$44 \%$

$\begin{array}{llll}36 \% & 63 \% & 3.86 & 0.049\end{array}$

$\begin{array}{llll}38 \% & 57 \% & 2.14 & 0.144\end{array}$

$29 \% \quad 57 \% \quad 5.14 \quad 0.023$

$30 \% \quad 56 \% \quad 4.20 \quad 0.040$

$33 \% \quad 47 \% \quad 0.94 \quad 0.332$

Did Pool Have Independent Licensing?

$\begin{array}{rrrr}\text { Yes } & \text { No } & \text { Chi-square } & \text { p-Value } \\ 0.81 & 1.48 & 2.01 & 0.049 \\ 1.11 & 1.61 & 2.23 & 0.024 \\ 5.75 & 3.57 & 1.80 & 0.076\end{array}$

$\underline{\text { Notes }}$

$* 0=$ no litigation; $1=$ litigation filed but case discarded; $2=$ litigated until ruling or settlement.

** $0=$ no licensing added; $1=$ new licensing but not mandatory licensing to 3rd parties; 2=RAND 3rd-party licensing added;

$3=$ royalty-free 3rd-party licensing added. 


\section{Table 4: Logit Regression Analyses of Independent Licensing Provision}

Resolution Score*
Licensing Remedy Score**
Log (Count of Pool Members)

Industry Dummy Variables?

Number of Observations

Chi-Squared Statistic

p-Value

Log Likelihood
Dependent Variable: Did Pool Have Independent Licensing?

$$
\begin{array}{r}
-0.65 \\
{[0.30]}
\end{array}
$$$$
-0.79
$$

** $\quad[0.37] * *$

$\begin{array}{cccc}-0.41 & -0.79 & -0.72 & -0.71 \\ {[0.21] *} & {[0.34] * *} & {[0.39] *} & {[0.35] * *} \\ & & 0.32 & 0.46 \\ & & {[0.70]} & {[0.74]}\end{array}$

$\begin{array}{rrr}\mathrm{N} & \mathrm{Y} & \mathrm{N} \\ & & \\ 61 & 61 & 59 \\ 4.81 & 12.48 & 3.99 \\ 0.028 & 0.188 & 0.046 \\ -39.67 & -35.84 & -38.49\end{array}$

\section{$\mathrm{N}$}

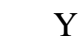

\section{$\mathrm{Y}$}

$\mathrm{Y}$

$\begin{array}{lrrr}59 & 59 & 61 & 59\end{array}$

$\begin{array}{llll}046 & 0.051 & 0.241 & 0.069\end{array}$

$-38.49-32.05 \quad-35.73 \quad-31.85$

\section{$\underline{\text { Notes }}$}

${ }^{*} 0=$ no litigation; $1=$ litigation filed but case discarded; $2=$ litigated until ruling or settlement.

** $0=$ no licensing added; $1=$ new licensing but not compulsory licensing to 3rd parties; 2=RAND 3rd-party licensing added; 3=royalty-free 3rd-party licensing added. Standard errors in brackets. 


\section{Table 5: Tabulations of Use of Grantback Requirement}

Grantback required
Grantback share difference, with

and without independent licensing

Grantback required

Grantback share difference, with

and without independent licensing
If Pool Was Not Litigated

$70.6 \%$

$6.7 \%$

If Mandatory 3rd-Party Licensing Not Added

$54.8 \%$

$10.1 \%$
If Pool Was Litigated

$34.9 \%$

$-19.3 \%$

If Mandatory 3rd-Party Licensing Added

$29.6 \%$

$-17.1 \%$
Chi-square p-Value

4.99

0.026 
Table 6: Logit Regression Analyses of Grant-Back Requirement

Pool Not Litigated?

No Mandatory 3rd-Party Licenses Added?

Pool Has Independent Licensing?

Independent Licensing and Not Litigated?

Independent Licensing and No Mandatory 3rd-Party Licenses Added?

Industry Dummy Variables?

Number of Observations

Chi-Squared Statistic

p-Value

Log Likelihood

Notes

Standard errors in brackets.
Dependent Variable: Did Pool Require Grant-Backs?

$$
\begin{array}{rr}
1.30 & 1.52 \\
0.60] * * & {[0.72]}
\end{array}
$$

0.53

[0.52]

0.96
$[0.68]$

$-0.09$

[0.52]

$$
\begin{array}{r}
-0.35 \\
{[0.60]}
\end{array}
$$

$$
-1.10
$$$$
2.08
$$$$
[0.89]
$$

.89] $* *$

$[0.84] *$

$0.84]$

2.39

$-1.10$

$1.50 \quad 2.15$

$[0.93] * \quad[1.18]$

$\begin{array}{rrr}\mathrm{N} & \mathrm{Y} & \\ & & \\ 62 & 62 & \\ 4.97 & 17.18 & 1.06 \\ 0.026 & 0.028 & 0.303 \\ -39.68 & -33.57 & -41.63\end{array}$

$\mathrm{N}$
62
1.06
0.303
1.63

$\mathrm{Y}$
62
14.31
0.07
-35.01

$\mathrm{N}$

Y

62

$-39.68$

$-33.57$

$-41.63$

$\begin{array}{ll}-35.01 & 0.867\end{array}$

62
12.57
0.128

6.24

$\mathrm{N}$
62
6.24

$\begin{array}{rrr}\mathrm{Y} & \mathrm{N} & \mathrm{Y} \\ 62 & 62 & 62 \\ 18.61 & 3.01 & 16.48 \\ 0.029 & 0.222 & 0.058\end{array}$

$\begin{array}{llll}-39.04 & -32.86 & -40.66 & -33.93\end{array}$ 